\title{
HUBUNGAN KEMAMPUAN MENGGAMBAR BENTUK DAN MENGGAMBAR ORNAMEN DENGAN HASIL BELAJAR MODIFIKASI MOTIF ORNAMEN BATAK ANGKOLA PADA SISWA SMP NEGERI 28 MEDAN
}

\author{
Listy Ennida Dalimunthe ${ }^{1 *}$, Sugito $^{2 *}$, Osberth Sinaga ${ }^{3 *}$, Nelson Tarigan $^{4 *}$ \\ Program Studi Pendidikan Seni Rupa Jurusan Seni Rupa Fakultas Bahasa dan Seni \\ Universitas Negeri Medan \\ Jl. Willem Iskandar Pasar V Medan Estate, Kec. Percut Sei Tuan, Kab. Deli Serdang, Kode Pos 27126. \\ Sumatera Utara. Indonesia. \\ Email: listymunthe959@gmail.com
}

\begin{abstract}
Abstrak
Penelitian ini bertujuan untuk mengetahui apakah ada hubungan kemampuan menggambar bentuk dan menggambar ornamen dengan hasil belajar modifikasi motif ornamen Batak Angkola. Objek yang digambar untuk menggambar bentuk adalah botol dan gelas dan motif yang digambar untuk menggambar ornamen adalah motif Batak Angkola. Adapun populasi dalam penelitian ini seluruh siswa kelas VII SMP Negeri 28 Medan dengan jumlah 240 siswa dan sampel yaitu kelas VII B yang berjumlah 30 siswa dengan menggunakan teknik cluster random sampling. Metode penelitian ini menggunakan penelitian correlational research. Hasil temuan penelitian menunjukkan bahwa terdapat hubungan kemampuan menggambar bentuk dan menggambar ornamen dengan hasil belajar modifikasi motif ornamen Batak Angkola, yang dibuktikan dengan $\mathrm{F}_{\text {hitung }}=23,74$ untuk dk= n-k-1 = $27 \alpha=0,05 \mathrm{~F}_{\text {tabel }}=3,35$ ternyata $\mathrm{F}_{\text {hitung }}>\mathrm{F}_{\text {tabel }}(23,74>3,35)$. Besar hubungan antara kemampuan menggambar bentuk dan menggambar ornamen dengan modifikasi motif ornamen Batak Angkola berkorelasi yaitu 0,71, dan besar sumbangan (kontribusi) yaitu sebesar $51 \%$.
\end{abstract}

Kata Kunci: menggambar, ornamen, modifikasi, Batak Angkola.

\begin{abstract}
This study aims to determine whether there is a relationship between the ability to draw shapes and draw ornaments with the results of learning to modify the Angkola Batak ornament motif. The objects drawn to draw shapes are bottles and glasses and the motif drawn for drawing ornaments is the Angkola Batak motif. The population in this study were all seventh grade students of SMP Negeri 28 Medan with 240 students and samples namely VII B class which amounted to 30 students using cluster random sampling technique. This research method uses correlational research. The results of the research show that there is a relationship between the ability to draw shapes and draw ornaments with the learning outcomes of modifications to the Angkola Batak ornament motif, as evidenced by Fcount = 23.74 for $d k=n k-1=27 \alpha=0.05$ Ftable $=3.35$ turns Fcount $>$ Ftable (23.74> 3.35). The magnitude of the relationship between the ability to draw shapes and draw ornaments with modifications to the Angkola Batak ornament motif is correlated at 0.71, and the contribution (contribution) is 15\%.
\end{abstract}

Keywords: drawing, ornament, modification, Angkola Batak.

\section{PENDAHULUAN}

Belajar merupakan proses dari pendidikan untuk meningkatkan sumber daya manusia, proses belajar pada umumnya dilaksanakan di sekolah dengan tentu cara mencapai tujuan yang ditetapkan sebagai capaian pembelajaran guru dan siswa. Berhasil tidaknya pencapaian tujuan belajar tergantung bagaimana proses belajar mengajar yang dijalani oleh siswa sebagai peserta dan tanggung jawab guru sebagai pendidik.

Sekolah Menengah Pertama dalam pelajaran seni Budaya dan Keterampilan menggambar merupakan proses perekaman atau tiruan dari bentuk sebuah benda (manusia, binatang, tumbuhan, dan lain-lain) yang dituangkan lewat media pensil atau sejenisnya di atas kertas gambar atau bidang datar. Sedangkan menggambar bentuk merupakan kategori seni rupa dua dimensi yang tidak lepas dari karakteristik bentuk yang terdiri dari gubahan bentuk benda.

Pelajaran menggambar bentuk dan menggambar ragam hias sebagai salah satu budaya lokal merupakan tugas dan tanggung jawab guru untuk mendidik siswa agar memiliki wawasan budaya kedaerahan. Adanya materi menggambar bentuk dan menggambar ragam hias pada mata pelajaran seni budaya dan keterampilan di sekolah SMP Negeri 28 Medan, siswa diharapkan dapat menambah kembangkan kreasi 


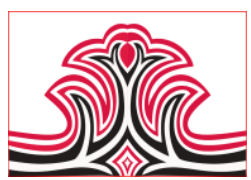

melalui karya seni rupa dua dimensi dengan kreatif dan aktif.

Berdasarkan pengamatan langsung kreativitas siswa SMP Negeri 28 Medan, secara teoritis pengetahuan siswa terhadap menggambar bentuk dan menggambar ornamen sudah memenuhi Kriteria Ketuntasan Minimal (KKM), dilihat dari nilai rata-rata siswa kelas VII SMP Negeri 28 Medan yang didapat dari guru mata pelajaran Seni Budaya dan Keterampilan yaitu 80 dengan nilai KKM 72.

Dalam menggambar bentuk siswa belum menguasai proporsi sehingga gambar terlihat kurang menarik, demikian juga dalam menggambar ragam hias siswa masih mencontoh motif yang sudah ada dan tidak mengembangkan motif yang dicontoh.

Ketidakdisiplinan siswa dalam mengkaji pelajaran Seni Budaya juga sangat berpengaruh pada hasil karya. Untuk memberikan motivasi dan semangat belajar yang tinggi maka, kemampuan dalam menggambar bentuk perlu ditingkatkan. Guru sebaiknya lebih bervariasi dalam metode pembelajaran agar kreativitas serta hasil belajar siswa dalam menggambar motif ragam hias (ornamen) dapat ditingkatkan lagi.

Kurangnya kreativitas siswa dalam pembelajaran menggambar bentuk dan menggambar ornamen menjadi permasalahan yang harus segera ditindak lanjuti agar pencapaian belajar dapat memenuhi jumlah nilai yang ditetapkan menurut KKM sekolah yaitu 72. Kurangnya kreativitas siswa dalam menggambar bentuk dan menggambar ragam hias (ornamen) dapat diantisipasi dengan meminta berlatih yang lebih rutin dan terarah dengan bimbingan teknis yang lebih mudah untuk dilakukan oleh siswa tersebut.

Dalam pelaksanaan menggambar bentuk dan menggambar ornamen memiliki perbedaan, namun pada prinsipnya sama-sama hasil pengamatan terhadap objek yang akan digambarkan. Proses penggambarannya dapat di katakan sama-sama diawali dari melihat objek. Karena itu tindakan pengetahuan kegunaan menggambar bentuk yang dimiliki objek dapat mempengaruhi kemampuan berkreasi pada menggambar ornamen?

\section{KAJIAN TEORI}

\section{Belajar}

"Belajar adalah suatu proses usaha yang dilakukan seseorang untuk memperoleh suatu perubahan tingkah laku yang baru secara keseluruhan, sebagai hasil pengalamannya sendiri dalam interaksi dengan lingkungannya. Perubahan tersebut akan nyata dalam seluruh aspek tingkah laku seseorang, baik perubahan pada dirinya maupun dalam kehidupan sehari-hari". (Slameto, 2010:2)
Gorga Jurnal Seni Rupa

Volume 08 Nomor 01 Januari-Juni 2019

p-ISSN: 2301-5942 | e-ISSN: 2580-2380

Menurut Prawiradilaga (2012:67) menjelaskan bahwa "Belajar tidak hanya merujuk pada aktivitas organ berpikir, otak. Belajar bertujuan untuk meningkatkan kualitas seseorang. Belajar adalah peningkatan kompetensi. Belajar menjadi salah satu upaya seseorang untuk mewujudkan cita-citanya. Belajar berkenaan dengan tatanan dan nilai yang ditularkan dari generasi ke generasi. Belajar menjadi salah satu peradaban manusia”.

Berdasarkan pendapat para ahli di atas, dapat disimpulkan bahwa belajar merupakan suatu proses untuk mendapatkan ilmu pengetahuan disertai adanya interaksi antara individu dengan individu lain maupun individu dengan lingkungannya sehingga terjadi perubahan tindakan atau perilaku pada diri individu dari semula tidak tahu menjadi tahu.

\section{Hasil Belajar}

Sudjana (2014:45) mengemukakan bahwa, "Hasil belajar siswa pada hakikatnya adalah perubahan tingkah laku sebagai hasil belajar dalam pengertian yang lebih luas mencakup bidang kognitif, afektif, dan psikomotorik. Dalam proses belajar mengajar di sekolah saat ini, tipe hasil belajar kognitif lebih dominan jika dibandingkan dengan tipe hasil belajar bidang afektif dan psikomotoris".

Menurut Sardiman (2009:3) juga menyebutkan "Hasil belajar merupakan hasil dari suatu interaksi tindak belajar dan tindak mengajar. Dari sisi guru, tindak mengajar diakhiri dengan proses evaluasi hasil belajar. Dari sisi siswa, hasil belajar merupakan berakhirnya pengajaran dari puncak proses belajar".

Kesimpulan dari hasil belajar adalah perubahan tingkah laku siswa dalam perubahan pengetahuan, sikap dan keterampilan serta pengetahuan dan pengembangan yang lebih baik dibanding sebelumnya.

\section{Modifikasi}

"Modifikasi adalah cara merubah bentuk sebuah barang dari yang kurang menarik menjadi lebih menarik tanpa menghilangkan fungsi aslinya,serta menampilkan bentuk yang lebih bagus dari aslinya". (Juragan, 2010)

Bahagia (2010:13), mengemukakan bahwa: Modifikasi dapat diartikan sebagai upaya melakukan perubahan dengan penyesuaian - penyesuaian baik dalam segi fisik material (fasilitas dan perlengkapan) maupun dalam tujuan dan cara (metoda, gaya, pendekatan, aturan serta penilaian)". (Fiedhie, 22:2012)

Dari pernyataan di atas mengenai pengertian modifikasi, modifikasi merupakan suatu usaha perubahan yang dilakukan berupa penyesuaianpenyesuaian baik dalam bentuk fasilitas dan 


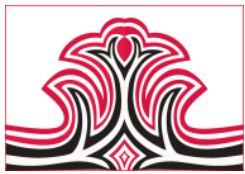

perlengkapan atau dalam metoda, gaya, pendekatan, aturan serta penilaian.

\section{Motif Ornamen Batak Angkola}

Mandailing, berbagai macam bentuk ornamen (hiasan) tradisional dapat kita temukan pada bagian tutup ari dari Sopo Godang (Balai Sidang Adat) dan Bagas Godang (Rumah Besar Raja). Dalam bahasa Mandailing, ornamen-ornamen tersebut disebut bolang yang juga berfungsi sebagai simbol atau lambang itu memiliki makna-makna yang sangat mendalam bagi masyarakat Mandailing.

Berdasarkan penjelasan-penjelasan di atas, dapat disimpulkan bahwa hasil belajar modifikasi motif ornamen batak angkola merupakan kemampuan yang diperoleh individu setelah proses belajar berlangsung, yang dapat memberikan perubahan tentang menggambar motif ragam hias serta pengetahuan, pemahaman, kreativitas dan keterampilan.

\section{Kemampuan Menggambar Bentuk 1).Kemampuan}

Robbin (dalam Wikipedia 2013) menyatakan bahwa "Kemampuan berarti kapasitas seseorang individu untuk melakukan beragam tugas dalam suatu pekerjaan". Lebih lanjut menyatakan bahwa kemempuan (ability) adalah sebuah penilaian terkini atas apa yang dapat dilakukan seseorang.

\section{2).Menggambar}

Apriyatno (2005:1) "Menggambar merupakan keterampilan yang bisa dipelajari setiap orang, terutama yang memiliki minat belajar. Menggambar adalah perpaduan keterampilan (skill), kepekaan rasa (teste), kreativitas, ide, pengetahuan dan wawasan".

Selanjutnya menurut Hill (1996:7) "Pada hakikatnya menggambar adalah pengungkapan oleh seseorang secara mental dan visual dari apa yang dialaminya dalam bentuk garis dan warna. Jadi menggambar tak lain adalah melukiskan apa yang terpikirkan dengam goresan-goresan pensil di atas kertas".

Berdasarkan beberapa pendapat tentang menggambar, dapat disimpulkan bahwa menggambar adalah suatu kegiatan memindahkan, meniru ide atau gagasan berupa bentu visual misalnya: manusia, benda, hewan, dan tumbuhan yang di buat dengan coretan pensil kedalam suatu bidang gambar.

\section{3).Menggambar Bentuk}

Menurut Mesra (2018:34) “Menggambar bentuk merupakan dasar dalam penggambaran benda-benda secara realis. Gambar bentuk bagaikan kamera atau tustel yang menangkap bentuk obyek apa adanya sesuai yang terlihat didepan fotografer".

Sedangkan menurut Sulistyo (2006:4) "Menggambar bentuk adalah memindahkan benda-benda yang diamati ke dalam bidang gambar (2 dimensi) sesuai dengan apa adanya. Gambar di ciptakan tanpa
Gorga Jurnal Seni Rupa

Volume 08 Nomor 01 Januari-Juni 2019

p-ISSN: 2301-5942 | e-ISSN: 2580-2380

memberikan rasa, ekspresi, kejiwaan pada gambar tersebut".

\section{4).Teknik Menggambar Bentuk}

Hareanto (2013:14) "Teknik menggambar bentuk adalah cara yang lazim yang dipergunakan untuk menggambar".

\section{Prinsip Menggambar Bentuk}

Menurut Mesra, dkk (2018:77) "Untuk dapat membuat gambar bentuk yang baik, harus memperhatikan beberapa prinsip seni rupa (desain). Prinsip seni rupa yang dimaksud adalah perspektif, komposisi, proporsi, dan gelap terang".

\section{Menggambar Ornamen}

Soepratno (1997:11), menjelaskan bahwa "Ornamen berasal dari bahasa Yunani yaitu kata "ornare" yang artinya hiasan atau perhiasan. Ragam hias atau ornamen itu sendiri terdiri dari berbagai jenis motif dan motif-motif itulah yang digunakan sebagai penghias sesuatu yang ingin kita hiasi. Oleh karena itu motif adalah dasar untuk menghias sesuatu ornamen".

Budiwiwaramulja dkk (2013:84) dalam jurnal nya yang berjudul Pengemasan Hasil Penciptaan Ragam Hias Dengan Aplikasi Elearning Authoring System, menjelaskan bahwa: Istilah ornamen digunakan oleh Meyer dalam "Handbook of Ornamen", diartikan sebagai elemen hiasan (dekorasi) yang diadaptasi, dikembangkan dari tumbuh-tumbuhan. Selanjutnya berkembang dengan karakter berbeda seperti geometrik dari bentuk ornagik (yaitu, batang, daun, bunga) serta bentuk anorganik. (Meyer, 1957:7).

Berdasarkan pendapat para ahli di atas, dapat disimpulkan bahwa ragam hias (ornamen) adalah suatu hiasan yang terdiri dari beberapa pola yang disusun secara berulang-ulang serta memiliki nilai kebudayaan dimana ragam hias ini sengaja dibuat dengan tujuan menghiasi benda atau produk.

\section{Teknik Menggambar Ornamen}

1).Stilasi

Menurut Sulastianto, (2008:4) "Stilasi merupakan motif hias yang memberikan suatu gaya atau mode untuk mendesain suatu bentuk motif hias agar tercipta variasi berbagai motif hias yang berbeda dan juga inovatif".

\section{2).Distorsi}

Menurut Sulastianto (2008:4) "Distorsi merupakan penyederhanaan motif-motif hias. Dimana distorsi dan stilasi merupakan kegiatan mengubah bentuk motif hias dengan melakukan penembahan atau penyederhanaan. Terkadang menyimpang dari bentuk aslinya sehingga sulit dikenali lagi”.

\section{3).Repetisi}

Menurut Sulastianto (2008:4) "Repetisi merupakan pengulangan motif-motif hias, motif digambarkan secara berulang-ulang. Repetisi ini juga merupakan 


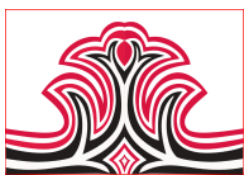

penggambaran motif-motif hias yang dapat diulangi agar terwujud motif hias yang inovatif'.

\section{4).Dekorasi}

Defenisi dekorasi diungkapkan oleh Sulastianto (2008:4) yang menjelaskan bahwa "Dekorasi yaitu hiasan yang dibuat untuk memperindah sesuatu agar kelihatan menarik".

\section{Unsur-Unsur Ornamen \\ 1).Garis}

Menurut Toekio (2000:15) dalam Hutabarat (2016:23) bahwa "Garis adalah deretan dari titik-titik yang berhimpit. Dari Ukuran, bentuk serta gerak yang ditimbulkannya, garis dapat berbentuk lurus, lengkungm patah-patah, bergelombang atau zigzag”.

\section{2).Bidang}

Menurut Toekio (2000:20) dalam Hutabarat (2016:24) mengemukakan bahwa "Suatu bidang akan lebih mengarah pada sifat yang berdimensi, berapapun kecil bidang dalam suatu desain bidang akan memberikan kesan tersebut. Bidang membentuk masa tertentu dengan batas yang nyata bahkan kadang-kadang dengan cukup kuat. Sifat dimensinya dalam bentuk membawa kesan dua atau tiga dimensi".

\section{3).Tekstur}

Menurut Toekio (2000:20) dalam Hutabarat (2016:24) bahwa "Dalam pembuatan ragam hias pemekaian tekstur banyak memberikan kesan atau bentuk kasar, halus, berbintik-bintik sesuai dengan penerapannya".

\begin{abstract}
4).Warna
Menurut Prawoto (1998:17) dalam Hutabarat (2016:25) bahwa "Dalam pembuatan ornamen kemairan irama karena penyusunan bentuk pengulangan dengan teratur dan terencana baik pengulangan bentuk maupun pengulangan warna".
\end{abstract}

\section{METODE PENELITIAN}

Metode penelitian yang digunakan dalam penelitian ini adalah penelitian korelasional (correlational research) penelitian yang melihat hubungan antara dua gejala (variabel). Penelitian ini adalah penelitian yang bertujuan mengetahui sejauh mana variabelvariabel berkaitan (berhubungan) berdasarkan koefisien korelasi.

Untuk mengumpulkan data dalam penelitian dilakukan dengan teknik tes. Sedangkan jenis tes yang dipakai adalah tes kemampuan menggambar bentuk, menggambar ornamen dan modifikasi motif ornamen Batak Angkola.

\section{HASIL DAN PEMBAHASAN \\ 1.Hasil}

Sesuai dengan teknik pengumpulan data yang menggunakan teknik tes, yaitu tes kemampuan menggambar bentuk dan menggambar ornamen dengan hasil belajar modifikasi motif ornamen Batak
Gorga Jurnal Seni Rupa

Volume 08 Nomor 01 Januari-Juni 2019

p-ISSN: 2301-5942 | e-ISSN: 2580-2380

Angkola. Hasil tes pertama, kedua dan ketiga diobservasi oleh ketiga orang penilai dengan maksud untuk mendapatkan nilai sebagai data yang valid.

Berdasarkan hasil penilaian menggambar bentuk menunjukkan bahwa secara umum dalam menggambar bentuk siswa kelas VII B SMP Negeri 28 Medan berada pada kategori C (Cukup), dengan jumlah nilai $=1819$ dan nilai rata-rata $=60,8$.

Kemudian hasil penilaian menggambar ornamen menunjukkan bahwa dalam menggambar ornamen siswa kelas VII B SMP Negeri 28 Medan berada pada kategori B (Baik), dengan jumlah nilai $=2214$ dan nilai rata-rata $=76,13$.

Selanjutnya hasil penilaian modifikasi motif ornamen menunjukkan bahwa dalam memodifikasi motif ornamen batak angkola siswa kelas VII B SMP Negeri 28 Medan berada pada kategori B (Baik), dengan jumlah nilai $=2219$ dan nilai rata-rata $=73,96$.

\section{Pembahasan}

Dari data yang dikumpulkan dengan tes praktik yaitu menggambar bentuk dan menggambar ornamen dan modifikasi motif ornamen Batak Angkola, setelah dinilai dan diperoleh data kemampuan menggambar bentuk $\left(\mathrm{X}_{1}\right)$, kemampuan menggambar ornamen $\left(\mathrm{X}_{2}\right)$ dan modifikasi motif Batak Angkola $(\bar{y})$, kemudian dianalisis dan diperoleh hasil sebagai berikut:

\section{1).Uji Normalitas}

Tabel 1. Hasil Analisis Uji Normalitas

\begin{tabular}{|r|c|c|c|r|}
\hline Variabel & $\mathbf{N}$ & $\mathbf{L}_{\text {Hitung }}$ & $\mathbf{L}_{\text {tabel }}$ & Ket \\
\hline Menggambar Bentuk & 30 & 0,155 & 0,161 & Normal \\
\hline Menggambar Ornamen & 30 & 0,154 & 0,161 & Normal \\
\hline Modifikasi Motif & 30 & 0,138 & 0,161 & Normal \\
Ornamen Batak Angkola & & & & \\
\hline
\end{tabular}

Berdasarkan tabel diatas maka diketahui bahwa data hasil menggambar bentuk berdistribusi normal yang dibuktikan dengan uji normalitas dimana nilai $L_{\text {hitung }}$ $0,155<L_{\text {tabel }} 0,161$. Selanjutnya untuk data hasil menggambar ornamen juga berdistribusi normal dengan nilai $L_{\text {hitung }} 0,154<L_{\text {tabel }} 0,161$. Kemudian untuk data hasil modifikasi motif ornamen Batak Angkola berdistribusi normal dengan nilai $L_{\text {hitung }}$ $0,138<L_{\text {tabel }} 0,161$. Berdasarkan keterangan pada tabel diatas dapat disimpulkan bahwa ketiga data variabel penelitian berdistribusi normal. 


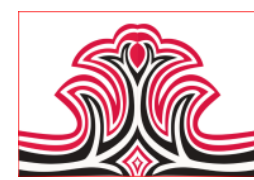

2).Uji Linierits

Tabel 2. Rangkuman Uji Linieritas antara X1 dengan Y

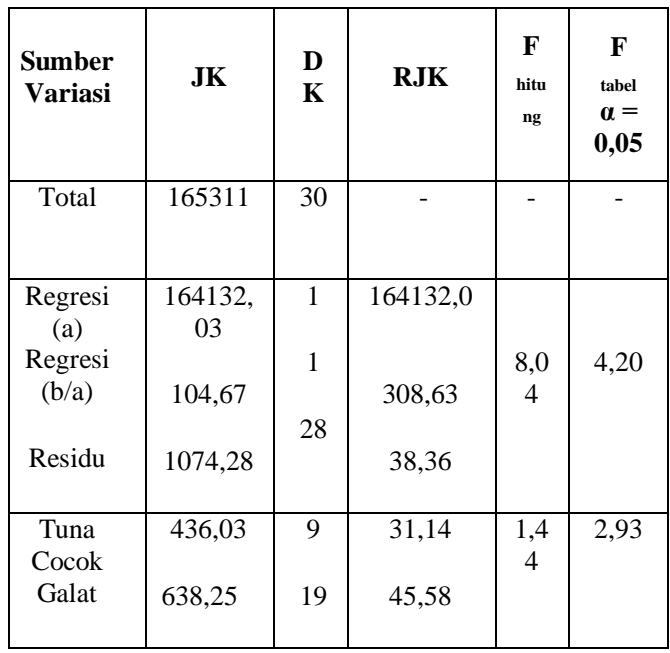

Berdasarkan Tabel diatas diperoleh bahwa $F_{\text {tabel }}$ dengan Dk (9:19) pada $\alpha=0,05$ adalah 2,93 sedangkan $F_{\text {hitung }}$ diperoleh sebesar 1,44 dan ternyata $F_{\text {hitung }}<F_{\text {tabel }}$ sehingga persamaan regresi tersebut adalah linier. Selanjutnya uji signifikan dengan Dk (1:28) pada $\alpha=0,05$ diperoleh $F_{\text {tabel }}=4,20$ sedangkan $c=8,04$ dan ternyata $F_{\text {hitung }}>F_{\text {tabel }}$ sehingga persamaan regresi $\mathrm{X}_{1}$ dan $\mathrm{Y}$ adalah signifikan. Dengan demikian dapat disimpulkan bahwa persamaan regresi $\hat{Y}=53,40$ $+0,33 \mathrm{X}_{1}$ mempunyai hubungan yang linier dan signifikan pada taraf kepercayaan $\alpha=0,05$.

\section{3).Analisis Korelasi}

\section{(1).Besar Hubungan}

Besar hubungan antara kemampuan menggambar bentuk dengan hasil belajar modifikasi motif ornamen Batak Angkola, besar hubungan diperoleh $\mathrm{r}_{\text {hitung }}=0,40$ berkriteria korelasi sedang. Bila menggunakan kriteria tabel product moment maka untuk taraf nyata $\alpha=0,05$ dengan $n=30$ kriterianya adalah 0,361 , harga $r$ yang peroleh melebihi kriteria ( $r_{\text {hitung }}>r_{\text {tabel }}$ ) dan tentunya berkorelasi sedang, dengan demikian dapat diartikan bahwa variabel $\mathrm{X} 1$ dan $\mathrm{Y}$ memiliki hubungan yang kuat.

Selanjutnya besar hubungan antara kemampuan menggambar ornamen dengan hasil belajar modifikasi motif ornamen Batak Angkola, besar hubungan diperoleh $r_{\text {hitung }}=0,97$ berkriteria korelasi sangat kuat. Bila menggunakan kriteria tabel product moment maka untuk taraf nyata $\alpha=0,05$ dengan $\mathrm{n}=30$ kriterianya adalah 0,361 , harga $r$ yang peroleh melebihi kriteria $\left(r_{\text {hitung }}>r_{\text {tabel }}\right)$ dan tentunya berkorelasi sangat kuat, dengan demikian dapat diartikan bahwa variabel X2 dan Y juga memiliki hubungan yang kuat.

\section{(2).Besar Sumbangan}

Besar sumbangan (kontribusi) antara kemampuan menggambar bentuk dengan modifikasi motif ornamen batak Angkola diperoleh $\mathrm{r}^{2=16 \%}$ artinya bahwa kemampuan menggambar bentuk (X1) memberi kontribusi atau masukan (sumbangan) pada
Gorga Jurnal Seni Rupa

Volume 08 Nomor 01 Januari-Juni 2019

p-ISSN: 2301-5942 | e-ISSN: 2580-2380

modifikasi motif ornamen batak Angkola (Y) rata-rata $16 \%$, sisanya $84 \%$ dari variabel lain.

Selanjutnya besar sumbangan (kontribusi) antara kemampuan menggambar ornmen dengan modifikasi motif ornamen Batak Angkola diperoleh $r^{2}=94 \%$ artinya bahwa kemampuan menggambar bentuk (X2) memberi kontribusi atau masukan (sumbangan) pada modifikasi motif ornamen batak Angkola (Y) rata-rata $94 \%$, sisanya $6 \%$ dari variabel lain.

\section{4).Uji Signifikan}

Signifikasi hubungan antara kemampuan menggambar bentuk dengan modifikasi motif ornamen Batak Angkola di peroleh $\mathrm{t}_{\text {hitung }}=1,73$ untuk $\mathrm{Dk}=\mathrm{n}-2=28 \alpha=0,05 \mathrm{t}_{\text {tabel }}=1,697$ ternyata $\mathrm{t}_{\text {hitung }}>$ $\mathrm{t}_{\text {tabel }}(1,73>1,697)$, artinya antara variabel $\mathrm{X} 1$ dan $\mathrm{Y}$ memiliki hubungan yang sangat signifikan atau yang berarti, antara kemampuan menggambar bentuk (X1) dengan modifikasi motif ornamen Batak Angkola (Y)

Selanjutnya signifikasi hubungan antara kemampuan menggambar ornamen dengan modifikasi motif ornamen Batak Angkola di peroleh $t_{\text {hitung }}=21,86$ untuk $\mathrm{Dk}=\mathrm{n}-2=28 \alpha=0,05 \mathrm{t}_{\text {tabel }}=1,697$ ternyata $t_{\text {hitung }}>t_{\text {tabel }}(21,86>1,697)$, artinya antara variabel $X 2$ dan Y memiliki hubungan yang sangat signifikan atau yang berarti, antara kemampuan menggambar ornamen (X2) dengan modifikasi motif ornamen Batak Angkola (Y).

\section{5).Uji Hipotesis}

Besar hubungan antara kemampuan menggambar bentuk dan menggambar ornamen dengan hasil belajar modifikasi motif ornamen Batak Angkola, besar hubungan diperoleh $\mathrm{r}_{\text {hitung }}=0,71$ berkriteria korelasi kuat. Bila menggunakan kriteria tabel product moment maka untuk taraf nyata $\alpha=0,05$ dengan $\mathrm{n}=30$ kriterianya adalah 0,361 , harga $\mathrm{r}$ yang peroleh melebihi kriteria $\left(r_{\text {hitung }}>r_{\text {tabel }}\right.$ ) dan tentunya berkorelasi kuat, dengan demikian dapat diartikan bahwa variabel kemampuan menggambar bentuk (X1) dan Kemampuan menggambar ornamen (X2) dengan modifikasi motif ornamen Batak Angkola (Y) memiliki hubungan yang kuat.

Besar sumbangan (kontribusi) antara kemampuan menggambar bentuk dan menggambar ornamen dengan modifikasi motif ornamen batak Angkola diperoleh $\mathrm{r}^{2}=51 \%$ artinya bahw kemampuan menggambar bentuk (X1) dan menggambar ornamen (X2) memberi kontribusi atau masukan (sumbangan) pada modifikasi motif ornamen batak Angkola (Y) rata-rata $51 \%$, sisanya $49 \%$ dari variabel lain.

Signifikasi hubungan antara kemampuan menggambar bentuk dan menggambar ornamen dengan modifikasi motif ornamen Batak Angkola di peroleh $\mathrm{F}_{\text {hitung }}=$ 23,74 untuk dk=n-k-1 = $27 \alpha=0,05 \mathrm{~F}_{\text {tabel }}=3,35$ ternyata $F_{\text {hitung }}>F_{\text {tabel }}(23,74>3,35)$, artinya antara 


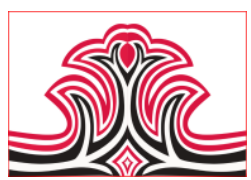

variabel $\mathrm{X} 1$ dan $\mathrm{X} 2$ dengan $\mathrm{Y}$ memiliki hubungan yang sangat signifikan atau yang berarti, antara kemampuan menggambar bentuk (X1) dam menggambar ornamen (X2) dengan modifikasi motif ornamen Batak Angkola (Y). Dengan demikian hipotesis $\mathrm{Ho}=0$ yang berbunyi diduga tidak ada hubungan yang signifikan antara kemampuan menggambar bentuk dan menggambar ornamen dengan modifikasi motif ornamen Batak Angkola ditolak, dan $\mathrm{Ha} \neq 0$ yang berbunyi diduga ada hubungan yang signifikan antara kemampuan menggambar bentuk dan menggambar ornamen dengan modifikasi motif Ornamen Batak Angkola diterima.

Dari penjelasan diatas dapat disimpulkan bahwa terdapat hubungan yang signifikan antara kemampuan menggambar bentuk dan menggambar ornamen dengan modifikasi motif ornamen Batak Angkola.

\section{KESIMPULA DAN SARAN 1.Kesimpulan}

Terdapat hubungan yang signifikan antara kemampuan menggambar bentuk dan menggambar ornamen dengan modifikasi motif ornamen Batak Angkola. Besar hubungan antara kemampuan menggambar bentuk dan menggambar ornamen dengan modifikasi motif ornamen Batak Angkola berkorelasi yaitu 0,71 . Besar sumbangan (kontribusi) antara kemampuan menggambar bentuk dan menggambar ornamen dengan modifikasi motif ornamen Batak Angkola yaitu sebesar 51\%, sehingga besar sumbangan menggambar bentuk terhadap modifikasi motif ornamen Batak Angkola memberikan dampak yang positif.

\section{Saran}

Dalam upaya meningkatkan kemampuan siswa dalam kegiatan menggambar bentuk dan ornamen maka disarankan:

Pihak SMP Negeri 28 Medan perlu untuk mengkaji lagi tentang perlunya meningkatkan wawasan dan kemampuan siswa dalam menggambar bentuk maupun menggambar ornamen dengan memberi waktu tersendiri dalam kegiatan menggambar bentuk dan ornamen. Pada guru bidang studi seni budaya sebaiknya dapat menambah wawasan dan kemampuan yang lebih dalam lagi tenggang menggambar bentuk dan ornamen, dengan tujuan agar kemampuan menggambar bentuk dan ornamen yang dimiliki akan memberikan masukan yang lebih besar dalam menunjang kemampuan siswa dalam menggambar bentuk dan ornamen yang lebih baik. Pada siswa agar dapat mengkaji kembali pentingnya memiliki kemampuan yang baik dalam menggambar bentuk dan ornamen utnuk keberhasilan dalam proses menggambar bentuk dan ornamen.
Gorga Jurnal Seni Rupa

Volume 08 Nomor 01 Januari-Juni 2019

p-ISSN: 2301-5942 | e-ISSN: 2580-2380

\section{DAFTAR RUJUKAN}

Apriyatno, Veri. (2005). Cara Mudah Menggambar Dengan Pensil. Jakarta: Kawan Pustaka.

Budiwiwaramulja, Dwi, dkk. (2013). Pengemasan Hasil Penciptaan Ragam Hias Dengan Aplikasi Elearninh Authoring System. Jurnal Seni Rupa, Vol 10 (01), 84-86.

Fiedhie. (2012). Pengertian Teori Modifikasi. http: //fiedhiemodifikasi. blogspot. Com /2012/08/ pengertian-modifikasi diakses pada 14 Juli 2018 pukul 14.42

Hill, H. (1996). The Indonesian Economy Since 1966: Southeast Asia's Emerging Giants. Cambridge: Cambridge University Press.

Hutabarat. (2013). Upaya Meningkatkan Hasil Belajar Siswa Dengan Menggunakan Pendekatan Contextual Teaching And Learning Pada Pokok Bahasan Raham Hias. Gorga Jurnal Seni Rupa, Vol 2 (2), 32-35.

Juragan. (2010). Pengertian Modifikasi. http://allabout-modif blogspot.com/2010/11/ pengertian-modifikasi.html diakses pada 14 Juli 2018 pukul 14.25

Mesra, dkk. (2018). Gambar Bentuk. Medan: Unimed Press.

Nasution, Edi. (2010). Ornamen Tradisional Mandailing.

www.apakabarsidimpuan.com/BolangOrnamen-Tradisional-Mandailing. Diakses pada 14 Juli 2018 pukul 14.42

Prawiradilaga, Dewi Salma. (2012). Wawasan Teknologi Pendidikan. Jakarta: Kencana Prenada Media Group.

Sardiman, A. M. (2009). Interaksi dan Motivasi Belajar Mengajar. Jakarta: Rajawali Perss.

Simatupang, Hareanto. (2013). Modul Menggambar Bentuk. Medan: Unimed Press.

Slameto. (2010). Belajar dan Faktor-Faktor yang Mempengaruhinya. Jakarta: Rineka Cipta.

Sirait, Bgainda. (1980). Desain Laposan Penelitian Pengumpulan Dan Dokumentasi Ornamen Tradisional Di Sumatera Utara. Pemerintah Daerah Tingkat I Privinsi Sumatera Utara.

Slameto. (2010). Belajar dan Faktor-Faktor yang Mempengaruhinya. Jakarta: Rineka Cipta. 